\title{
Traumatic subcutaneous haematoma causing skin necrosis
}

\author{
Matthew Megson \\ Warwick Medical School, Coventry, West Midlands, UK \\ Correspondence to Mr Matthew Megson,m.megson@warwick.ac.uk
}

\section{Summary}

A 79-year-old female, presented to accident and emergency with a painful right leg from the knee distally, after tripping. On examination, her right lower leg had a haematoma on the anterolateral aspect which was very tender. After 4 days, the patient was taken to theatre for debridement, and the wound was washed out. The next day, the wound was reconstructed with a split skin graft.

\section{BACKGROUND}

This case acts as a reminder of an important clinical lesson. If a haematoma is left untreated and the pressure within the haematoma exceeds the blood pressure in the dermal and subdermal capillaries, it may result in a large area of necrosis of the overlying skin. Therefore, an urgent evacuation of the haematoma must be performed to release the tension over the skin. ${ }^{12}$

\section{CASE PRESENTATION}

The patient was a 79-year-old-female, presented with a painful right leg from the knee distally. She had tripped over a step on the day of admission. She had no loss of conscious, though was unable to weight bear on her right leg. She had bilateral deep venous thrombosis (DVT) in 1994, she has asthma, hypertension, osteoporosis and macular degeneration. She was on multiple inhalers, warfarin, lansoprazole and antihypertensives. She lives alone, and before the accident, was independent and mobile with one stick. She doesn't smoke and doesn't drink alcohol. On examination her right hip had a mild ache though had no tenderness, bruising or swelling. Her right lower leg had a haematoma of approximately $20 \times 10 \mathrm{~cm}$ on the anterolateral aspect which was very tender. There was no neurovascular deficit and good bilateral pulses of both posterior tibial and dorsalis pedis. The roof of the haematoma was tense, and there was diffuse discolouration of the entire right lower leg.

\section{INVESTIGATIONS}

$\mathrm{X}$-rays showed no fractures.

\section{DIFFERENTIAL DIAGNOSIS}

Compartment syndrome was ruled out without a fasciotomy. Fractures were ruled out with an x-ray. Haematoma was therefore diagnosised.

\section{TREATMENT}

The plan on admission was to wait and watch, as the haematoma was not too large, and there did not seem to be any other major trauma. However, as the patient was on warfarin, the haematoma enlarged. Thus on the second day, after admission, the on-call plastic surgical surface plasmon resonance called as 'blisters' had been noticed over the swelling. He noted loss of epidermis and fixed staining of the skin over the haematoma. He made two incisions vertically along the length of the haematoma and washed out as much as possible with $0.9 \%$ saline, as well as listing her. On the fourth day, after admission, she was taken to theatre for debridement of the right lower limb haematoma, it was washed out with hydrogen peroxide and saline. The necrotic skin flap was then excised, finally topical negative pressure was applied. On the fifth day, after admission, she returned to theatres for a final washout and wound reconstruction with a split skin graft from her right thigh. Both wounds were dressed, and she was to mobilise after 48 hours. Haematology advised that, prophylactic dose of clexane is an adequate venous thromboembolism prophylaxis, as last DVT was 4 years ago, and the treatment dose has an increased risk including an increased risk of graft failure.

\section{OUTCOME AND FOLLOW-UP}

Graft check in 10 days and a donor site check in 14 days were done. The patient was then transfered to a rehabilitation facility for a period of 6 weeks, then it is planned to discharge her.

\section{DISCUSSION}

A haematoma is an extravasation of blood outside the blood vessels. The patient had a subdermal haematoma. Large haematomas form into hard masses under the surface of the skin. This is caused by the limitation of the blood to escape a subcutaneous or intramuscular tissue space as they are isolated by fascial planes. This is a key anatomical feature, that prevents such injuries from causing massive blood loss. In most cases the sac of blood or hematoma eventually dissolves. However, as in the case of the patient, they may continue to grow.

There are two distinct methods which are usually used for evacuating a haematoma:

Technique 1: needle aspiration ${ }^{3}$ Although still widely used, this method is no longer recommended by many sources because of hematoma reaccumulation. The aspiration is often inadequate and the haematoma requires additional management. 


\section{BMJ Case Reports}

Technique 2: incision and drainage ${ }^{4}$ If the skin over the centre of the haematoma is thin and tense and shows signs of skin necrosis, the incision should not be made at this point. Instead, it should be made at the periphery of the haematoma, where the skin shows a normal appearance. Similarly, the incision should not be made crosswise to the lines of tension. The incision must be clean and direct and it must penetrate the entire thickness of the skin at one stroke and at even depth along its entire length. The incision should be made at right angles to the surface of the skin so that the skin edges may meet perpendicularly when healed.

There is a third method of evacuating a haematoma is a liposuction method, which is very rarely used in the UK. ${ }^{1}$
Competing interests None.

Patient consent Obtained.

\section{REFERENCES}

1. Chami G, Chami B, Hatley E, et al. Simple technique for evacuation of traumatic subcutaneous haematomas under under tension. BMC Emerg Med 2005;5:11.

2. Ascari-Raccagni A, Baldari U. Liposuction surgery for the treatment of large hematomas on the leg. Dermatol Surg 2000;26:263-5.

3. Leybell I. Auricular Hematoma Drainage. In: Meyers AD, ed. Medscape reference 2009.

4. Vazirani SJ. Incision and drainage: a new modified surgical technique. Oral Surg Oral Med Oral Pathol 1961;14:651-7.

\section{Learning points}

- To check the vascularity of the skin above and around the haematoma then you need to know three things. Is the skin tense, discoloured, and does it blanch?

- If the vascularity of the skin around a haematoma is in question, then a member of the plastic surgical team should be called to assess the patient.

- Haematomas should be evacuated usually by incision and drainage if the skin above the haematoma is or is likely to become vascularly compromised, this will avoid skin necrosis occurring over the haematoma.

- If the skin over the haematoma does become necrotic, then the patient needs to be listed for emergency surgery to evacuate, debride and reconstruct the wound.

- When patients on anticoagulants (eg, warfarin) are admitted with a haematoma, then extra care should be taken to ensure the haematoma is not still expanding. Senior help should always be sought if this is the case.

This pdf has been created automatically from the final edited text and images.

Copyright 2011 BMJ Publishing Group. All rights reserved. For permission to reuse any of this content visit http://group.bmj.com/group/rights-licensing/permissions.

BMJ Case Report Fellows may re-use this article for personal use and teaching without any further permission.

Please cite this article as follows (you will need to access the article online to obtain the date of publication).

Megson M. Traumatic subcutaneous haematoma causing skin necrosis. BMJ Case Reports 2011;10.1136/bcr.05.2011.4273, date of publication

Become a Fellow of BMJ Case Reports today and you can:

- Submit as many cases as you like

- Enjoy fast sympathetic peer review and rapid publication of accepted articles

- Access all the published articles

- Re-use any of the published material for personal use and teaching without further permission

For information on Institutional Fellowships contact consortiasales@bmjgroup.com

Visit casereports.bmj.com for more articles like this and to become a Fellow 